\title{
IMPACT OF METHIONINE AND BETAINE OR BOTH ON THE PERFORMANCE OF BROILERS FED LOW PROTEIN DIETS: 1- GROWTH PERFORMANCE, CARCASS CHARACTERISTICS, AND ECONOMICAL EVALUATION
}

\author{
Nematallah G.M. Ali' ${ }^{1}$ A.I. El-Faham ${ }^{1}$; and Reham A.M. Ali ${ }^{2}$ \\ ${ }^{1}$ Poult. Prod. Dept., Fac. of Agric., Ain Shams Univ., Egypt. \\ ${ }^{2}$ Animal and Poult. Prod. Dep., Fac. of Agric. and Natural Resources, Aswan Univ., Egypt.
}

\section{SUMMARY}

$\mathrm{T}$

his investigation aimed to evaluate the effect of methionine and/or betaine supplementation on performance, carcass characteristics and economic efficiency of broilers that fed low protein diets. A total numbers of 180 one day old unsexed Hubbard broiler chicks were divided into six treatments (30 birds each). Each treatment contained 3 replicates of 10 birds. Two levels of dietary crude protein (recommended, $\left.\mathrm{D}_{1}\right)$ control diet, and low protein $\left(-2 \%\right.$ crude protein, $\left.\mathrm{D}_{2}\right)$, treatment diets $\left(\mathrm{T}_{1}-\mathrm{T}_{5}\right)$ and DL- methionine (MET), or betaine (BET), were added in experimental treatment diet as follows:

1- Chicks were fed control diet $\left(\mathrm{D}_{1}\right)$

2- Chicks were fed low protein diet (-2\% crude protein, $\left.\mathrm{D}_{2}\right)$

3- Chicks were fed D2 + 100\% MET

4- Chicks were fed D2 + 50\% MET $+50 \%$ BET

control

5- Chicks were fed D2 $+25 \%$ MET $+75 \%$ BET

All diets (control and $\mathrm{T}_{1-5}$ ) were equal in lysine \% while MET add in the T2 diets up to control diet.

The results indicated that:

1- Body weight gain during whole experimental period were not significantly affected by different dietary treatments, where feed intake, and feed conversion ratio performance index (PI) and production efficiency factor (PEF) were significantly affected. Moreover chicks fed the high protein diets reflected the highest body weight gain value and the best in feed conversion compared with those fed the low protein diets $\left(\mathrm{T}_{1}\right.$ 5).

2- Carcass characteristics parameters \% (carcass, liver, gizzard, heart, giblets and total edible parts) showed in some cases the highest significant figures when broiler chicks fed diets containing BET $\left(\mathrm{T}_{4}\right.$ and $\left.\mathrm{T}_{5}\right)$ compared to other treatments.

3- Economic efficiency values were improved in chicks fed low protein diets supplemented with MET and/or BET as compared with those fed unsupplemented diets and chicks fed control diet showed the highest economical evaluation compared with the other treatments $\left(\mathrm{T}_{1-5}\right)$.

Therefore, it could be concluded that MET and BET supplementation have been recommended in low-protein broiler diets to support and enhance economic efficiency.

Keywords: Methionine, betaine, performance, carcass characteristics and economical evaluation.

\section{INTRODUCTION}

In the poultry industry, it is well known that the use of low crude protein with correct AA supplementation is an effective method to reduce feed costs (Firman, 1994), nitrogen excretion and ammonia emissions in poultry production (Kidd et al., 1996; Ferguson et al., 1998; Blair et al., 1999; Nahm, 2002 and Namroud et al., 2008), and this reduced the polluting effect on soil and water by reducing $\mathrm{N}$ dropping content (Holsheimer and Jensen, 1992).

Reducing dietary crude protein (CP) increased the efficiency of utilization of dietary $\mathrm{CP}$, reduced nitrogen excretion intestinal disorders, the level of ammonia in litter, minimizing amino acid excesses, improve poultry tolerance to high ambient. Temperatures and maximizing profitability (Leeson et al., 2001 and Coon, 2004).

On the other hand, protein is one of the most expensive components of poultry rations. Therefore, any approach that could potentially reduce the intake, and as a result, the excretion of the nutrient without 
affecting the hen's productivity would have a significant impact in reducing the environment al pollution (Nahashon et al., 2007). In an earlier study (Koreleski and Swiatkiewicz, 2009) hens fed a lower protein content $(16.5 \%)$ diet reacted positively to methionine supplementation, achieving higher laying performance and egg mass and improved nitrogen balance.

Also, the results of many previous reports demonstrated that chicks which had received low-CP corn soybean meal diets fortified with AA,s performed equally well as those which had received the positive control diet,Holsheimer et al. (1992) and Sinova et al. (2010).

However, due to technological advances some essentials amino acids [methionine, lysine, threonine and tryptophan] have become economically available in recent years and there is a good possibility that others will be commercially available in the future. Recent reports indicated that promising results can be obtained by the use of low-protein, amino acid supplemented diets for laying hens (Keshavaraz and Austic, 2004).

DL- methionine is normally considered to be the first limiting amino acid in poultry diets. In general, amino acid balance and nitrogen retention are improved by methionine supplementation. Hassan et al (2003) using Mandara and Abdalla (2005) using Gimmizah found insignificant difference on final body weight by increasing dietary methionine level in their diets. Hassan et al. (2003) observed that increase daily intake of methionine was accompanied by significant improvement in egg production and feed conversion. Centenary, Abdalla et al. (2005). Showed the opposite result Naulia and Singh (2002) found that using different levels of methionine significantly improved digestibility coefficient of organic matter, crude protein. On the other hand, El-Husseiny et al. (2005) observed that DL- methionine supplementation had no significant effect on digestibility coefficient values of nutrients.

Betaine, the common term is a naturally occurring amino acid derivative found in a variety of feedstuffs of plant and animal origin. Betaine has two primary metabolic roles: it is a methyl group donor and it is an osmolyte that assists in cellular water homeostasis (Petronine et al., 1992).

Betaine, choline and methionine can serve as sources of methyl $\left(-\mathrm{CH}_{3}\right)$ group. It is well understood that choline may acts as methyl group donor, but in order to function as a methyl group donor, it needs to be converted to betaine in the mitochondria (Molitoris and Baker, 1976 and Rostangose et al., 1996). Many studies have examined the interrelationship between betaine and methionine to determine if these compounds can spare the needs of the chick for methionine with considerable variation in results, while some studies (Virtanen and Rossi, 1995) suggest that the response of broiler growth to betaine was greater than the obtained from the addition of methionine, other have failed to demonstrate that the methionine content of the diet could be reduced by supplementation with betaine (Rostangose and Pack, 1996 and Mc Devitt et al., 2000 and El-Ganzory et al., 2004). However, several studies suggest that addition of betaine may improve breast meat yield (Schutte et al., 1997; Mc Devitt et al., 2000). Betaine is indirectly involved in the synthesis of carnitine, which is required for transporting long chain fatty acids across the inner mitochondrial membrane for oxidation (Mc Devitt et al., 2000) and therefore, may result in a baner carcass.

Betaine is added to the feed and consequently contributes to enhanced productivity which could have an important economic value (Park et al., 2006).

Furthermore, betaine promotes intestinal microbes against osmotic variations and improves microbial fermentation activity, which in turn, may enhance nutrient digestibility (Ratriyanto et al., 2009).

Therefore, the aim of this study was to investigate the effect of methionine and/or betaine supplementation in the low-protein diets on the performance, carcass characteristics, and economical efficiency of broiler chickens.

\section{MATERIALS AND METHODS}

The Present experiment was carried out at the poultry experimental unit, Agricultural experiment and Research Station at Shalakan, Faculty of Agriculture, Ain Shams University.

\section{Birds, diets and management:}

A total numbers of 180 one-day old unsexed Habbard broiler chickens were divided into six treatments (30 birds each), each treatment contained 3 replicates of 10 birds each. Chicks were reared in an environmentally controlled roomwith a continuous light and fans for ventilation and were fed starter diet from 0 to 3 weeks of age and grower diet from 4 weeks of age to the end of the experiment at 5 weeks of age (corn-soy bean meal diet). Feed and water were supplied ad libitum. Two levels of dietary crude protein (Recommended $\left(D_{1}\right)$ control diet and low protein diet containing $2 \%$ lower protein, 
treatment diets $\left(\mathrm{T}_{1}-\mathrm{T}_{5}\right)$ and DL-Methionine $(\mathrm{MET})$ or Betaine (BET) were added in experimental treatment diet as follows:

1- Chicks were fed the control diet $\left(\mathrm{D}_{1}\right)$

(Control)

2- Chicks were fed $-2 \%$ crude protein $\left(\mathrm{D}_{2}\right)$

3- Chicks were fed $\mathrm{D}_{2}+100 \%$ MET

4- Chicks were fed $\mathrm{D}_{2}+50 \% \mathrm{MET}+50 \% \mathrm{BET}$

5- Chicks were fed $\mathrm{D}_{2}+25 \% \mathrm{MET}+75 \% \mathrm{BET}$

6- Chicks were fed $\mathrm{D}_{2}+100 \%$ BET

The added MET up to control diets in the T2 diets was partially (50\% and 75\%) or completely (100\%) replaced by BET in diets $\mathrm{T}_{3}, \mathrm{~T}_{4}$ and $\mathrm{T}_{5}$ respectively. All diets (control and $\mathrm{T}_{2}-\mathrm{T}_{5}$ ) were equal in lysine $\%$. BET was added as $97 \%$ - dry crystalline Betafin BT. Composition and calculated analysis of the experimental diets are presented in Table 1.

The vaccination program adopted by recommended requirements according to standard commercial guidelines.

\section{Performance of chicks:}

The performance of broiler chicks, fed control diet or low protein diets supplemented with BET as partial or complete substitutes for supplemental dietary recommended MET, was evaluated in terms of live body weight (LBW).Birds were individually weighed to the nearest gram at 0,3 and 5 weeks of age intervals during the experimental period. At the same time, feed intake (FI, g) was recorded and feed conversion ratio (FCR, g feed: g gain) and live body weight gain (LBWG) were calculated. Accumulative mortality rate was obtained by adding the number of dead birds during the experiment divided by the total number of chicks at the beginning of the experimental period.

\section{Carcass traits:}

At the end of experiment period ( 5 weeks of age), slaughter tests were performed using three chicks around the average mean of LBW of each treatment. Birds were individually weighed to the nearest gram, and slaughtered by severing the jugular vein. After bleeding each birds was dipped in a water bath and feathers were removed. After the removal of head, carcass were manually eviscerated to determine some carcass traits, dressing \% and total giblets \% (Gizzard empty, liver, and heart). The abdominal fat was removed by hand from the parts around the viscera and gizzard and was weighed to the nearest gram.

\section{Economical evaluation:}

The economic efficiency was calculated as the price of body weight - total costs of raising chickens as relative to total raising costs.

\section{Statistical analysis:}

Data were statistically analyzed according to ANOVA procedures of SAS (SAS Institute, 2002). Means differences were compared using Duncan's Multiple Range Test (Duncan, 1955).

\section{RESULTS AND DISCUSSION}

\section{Productive performance:}

Results in Table (2) showed the effect of different dietary supplementation on the growth performance of growing chicks from the followings:

\section{Body weight gain:}

It is worth to note that the chicks fed low protein diet without or with MET $\left(\mathrm{T}_{1}\right.$ and $\left.\mathrm{T}_{2}\right)$ during starting period (0-3 wks.) of age reflected the lowest significant $(\mathrm{P}<0.05)$ result in body weight gain $(\mathrm{BWG})$ compared with control group, and the corresponding figures were 761.38, 769.33 and $837.50 \mathrm{~g}$ respectively as shown in Table (2).

On the other hand, chicks fed $\left(50 \%\right.$ MET $+50 \%$ BET) $\mathrm{T}_{3}$ gave slightly higher body weight gain $(814.33 \mathrm{~g})$ compared to those fed diets containing higher levels of BET $75 \%$ or $100 \%$, being 809.00 and $783.83 \mathrm{~g}$ respectively, the differences were statistically not significant.

During the growing experimental period (4-5 wks.), values of BWG showed no significant differences among groups fed different experimental diets and the corresponding values for BWG ranged between $1152.43 \mathrm{~g}$ and $1084.27 \mathrm{~g}$. 
Moreover, the response of body weight gain to different treatments was not significant from (0-5) wks. of age, but $\left(T_{1}, T_{3}\right.$ and $\left.T_{5}\right)$ have the best body weight gain compared with other treatment groups and closely to control. That's means, the depression in growth performance due to the effect of the low protein diet $\left(\mathrm{T}_{2}\right)$ was more pronounced during starting rather than growing periods. This might be due to the fact that, older birds have more tolerance and more adaptability for feed deficiency than the younger birds (Lesson and Summers, 1991). Sinova et al., (2010) indicating that young broilers might be more sensitive to changes in diet quality than older broilers.

In addition, methionine and betaine have been improved performance due to these supplementation could be attributed to several reasons, e.g. as methyl donor group, its diverse physiological properties that could improve gut environment and thus enhance the ability of the chicks to withstand coccidial infection, reduce intestinal membrane damage, dehydration, diarrhea and mal-digestion and/or absorption (Kettunen et al., 2001). In addition, Sayed and Downing (2011) found that the addition of betaine at an inclusion rate of $500 \mathrm{mg} / \mathrm{L}$ in drinking water improved body weight of broiler chicks under heat stress.

From mentioned results, it could be concluded that betaine and methionine supplementation play a pivotal role in changes of the insulin-like growth factor system (IGFs), which increased the secretion of blood insulin-like growth factor binding protein-3 (IGFBP-3), consequently extended the half-life of blood IGF-1 and increased proservability, enhancing the productivity and liver tissue differentiation (Park et al., 2006). Also, it could reduce the requirement for other methyl group donors and its osmotic properties as well as the potential to improve the digestibility of specific nutrients (Remus et al., 2004), moreover, it was improved protein and fatty acid synthesis in the liver (Rima, 2013).

\section{Feed intake and feed conversion:}

Data in Table (2) indicated that feed intake per bird $(\mathrm{g})$ was significantly $(\mathrm{P}<0.05)$ increased by feeding low protein diet $\left(\mathrm{T}_{1}\right)$. The increase in feed consumption was more pronounced during starting period (0-3 wks.) being (7.6\%), while it was (7.2\%) during growing period (4-5 wks.). This might be due to the fact that starter $\left(\mathrm{T}_{1}\right)$ diet contained lower protein and other essential A.A. contents compared to the control diet. Increasing feed consumption could be related to fact that broiler chicks consume more feed to meet energy to maximize growth during short rearing periods. Feed conversion showed the same trend since chicks fed control diet were more efficient in converting their food into gain compared with those fed low protein diets and differences were significant $(\mathrm{P}<0.05)$.

On the other hand, it was obvious from (Table 2) that the effect of either MET or BET on feed consumption and feed conversion during different experimental periods showed no significant differences among groups fed different dietary treatments $\left(\mathrm{T}_{2-5}\right)$ compared to control group. The corresponding values for FI ranged between 3328 and $3480 \mathrm{~g}$, while FCR ranged between 1.76 and 1.83. The differences were statistically not significant.

These results disagree with Junqueira et al. (2006) who reported that feed intake was significantly decreased with the decreased protein.

Although, the improvement of feed conversion was slightly compared to control, but this improvement may be due to betaine and methionine supplementation had effect as methyl donor and its diverse physiological properties that could improve gut environment and thus enhance the ability of absorption (Remus et al., 2004), also, it may be enhanced utilization of dietary amino acids for protein synthesis and release a fewer amino acids available for deamination and eventual synthesis of adipose tissue or to support intestinal growth, function, increased cell proliferation and improve microbial fermentation activity, which in turn may enhance nutrient digestibility (Ratriyantoet al., 2009).

Betaine accumulation in the cell may protect it from osmotic stress and allows to continue regular metabolic activities in conditions that would normally inactivate the cell (Saunderson and Mackinlay, 1990). These results are similar to those obtained by Park et al (2006) who suggested that dietary betaine could improve feed conversion of laying hens. Zayed (2012) reported that feed conversion ratio was insignificantly improved by supplementing both 0.75 and $1.5 \mathrm{~g}$ betaine $/ \mathrm{kg}$ to turkey diets under summer condition. On the other hand, Ryu et al. (2003), Wang et al. (2004) and El-Husseiny et al. (2007) reported that feed conversion was significantly improved by increasing betaine levels up to $0.75 \mathrm{~g} / \mathrm{kg}$ diet. Also, Tollba and El-Nagar (2008), Attia et al. (2005) and Ezzat et al. (2011) reported that supplementing $1.0 \mathrm{~g}$ betaine $/ \mathrm{kg}$ diet resulted in significant improvement in feed conversion ratio compared to the control under summer conditions.

\section{Carcass characteristics:}

Table (3) shows the effect of different dietary treatments on carcass characteristics for the chicks slaughtered at the end of wks. of age. Experimental treatments with BET $\left(\mathrm{T}_{3-5}\right)$ had no significant effect on studied parameters compared with control. The corresponding values for dressing percentages ranged 
between 73.2 and $75.3 \%$, while total edible parts (hot carcass + giblets weight) percentages ranged between 75.07 and $77.33 \%$.

On the other hand, the chicks fed low protein diet with MET $\left(\mathrm{T}_{2}\right)$ gave the lowest figures of 70.2 and $74.15 \%$ for dressing and total edible parts percentages respectively and the differences were significant $(\mathrm{P}<0.05)$ compared with the control group in total edible parts figures.

Similar observations have been reported by Ganesan (2010) they concluded that weight of the hot carcass and eviscerated carcass as well as carcass yield was not affected by dietary treatments although no effect of increased levels of digestible methionine + cysteine on absolute or relative weight of the organs (heart liver and gizzard). On the other hand, these findings were in contrast with results obtained by Hassan et al. (2005) and Nafal et al. (2014) who stated that dietary supplementation betaine improved carcass yield, breast and giblets percentages than the control group. In spite of abdominal fat was not significantly different among treatments and control group. Birds that fed on T4 decreased abdominal fat than other treatments and control. These results reflected that methionine and betaine may interact with the lipid metabolism by stimulating the oxidative catabolism of fatty acid via its role in carnithine synthesis. Thus offering a potential for reduced carcass fatness in commercial production (Schutte et al., 1997 and Konca et al., 2008).

\section{Economical evaluation:}

Results of economic efficiency for chickens fed experimental diets during the growth period (0-5 wks.) are summarized in Table (6). The price figures are based on the recent prices of local Egyptian market for feed additives, feed ingredients and selling price of live chickens in Qaliobeya region, Egypt. However, the price of different tested diets ranged from 3708 to $3517 \mathrm{LE} /$ ton (starter diets) and 3517 to $3329 \mathrm{LE} /$ ton (grower diets). Feed additives (MET and BET) treatments raised the price of tested diets as compared to supplemented diets and the corresponding values were ranged from 3590 to $3575 \mathrm{LE} /$ ton (starter diets) and 3362 to 3356 (grower diets). However, it is interesting to state that the chicks fed $\mathrm{T}_{2}$ diets gave the lowest chick cost feeding (LE) compared with the other treatments and the relative reduction in feeding cost per chick was 11.41 LE as shown in Table (6). However, the obtained results showed that incorporated BET on the expense of MET decreased the calculated relative economic efficiency percentages of broiler chicks and the corresponding figures were 90, 79, 80 and 86 respectively, while using low protein diets without feed additives $\left(\mathrm{T}_{2}\right)$ showed the lowest economic evaluation percentage (73) compared to those fed control diets being (100\%).

These results are in agreement with those obtained by Shahzad et al. (2011) who stated that the broiler fed lysine plus methionine supplemented low $\mathrm{CP}$ ratio proved to be more profitable when compared with the broiler under low $\mathrm{CO}$ ratio without essential amino acids.

\section{REFERENCES}

Abdalla, A.; H.M. Yakout and M.M. Khalifah (2005). Determination of lysine and methionine requirements of Gimmizah strain during egg production stage. $3^{\text {rd }}$ Inter. Poult. Con. 4-7 Apr. 2005. Hurghada. Egypt.

Attia, Y.A.; R.A. Hassan; M.H. Shehatta and S.B. Abdel-hady (2005). Growth, carcass quality and serum constitutents of slow growing chicks as affected by betaine to diets containing 2-Different levels of methionine. Inte. J. Poult. Sci., 4: 856-865.

Blair, R.; J.P. Jacob; S. Ibrahim and P. Wang (1999). A quantitative assessment of reduced protein diets and supplements to improve nitrogen utilization. Appl. Poult. Res., 8: 25-47.

Nofal, M.E.; Magda, A. Galal; S.M.M. Mousa; Doaa, M.M. Yassien and A.M.A. Bealsh (2014). Effect of dietary betaine supplementation on productive, physiological and immunological performance and carcass characteristic of growing developed chicks under the condition of heat stress. Egypt. Poult. Sci., 35(1):237-259.

Coon, C. (2004). The ideal amino acid requirement and profile for broilers, layers and broiler breeders. The American Soybean Association. July, 2004.

Duncan, D.B. (1995). Multiple Range and multiple F-test. Biometrics, 11:1-42.

El-Ganzory E.H.; R.A. Hassan and Kout El-Kloub M.E. Moustafa (2004). Effect of betaine and/or sodium sulphate supplementation as a substitute for methionine in chick diets. Egypt. Poult. Sci., 24:823-843.

El-Husseiny, O.M.; A.Z. Soliman; M.O. Abd El-Samee and I.I. Omara (2005). Effect of dietary energy, methionine, choline and folic acid levels on layers performance. Egypt. Poult. Sci., 25: 931-956. 
Ferguson, N.S.; R.S. Gates; J.L. Taraba; A.H. Cantor; A.J. Pescatore; M.J. Ford and D.J. Burnham (1998). The effect of dietary crude protein on growth, ammonia concentration and litter composition in broiler. Poult. Sci., 77:1481-1487.

Firman, J.D. (1994). Utilization of low protein diet for turkey. Biokyowa Technical Review 7.

Ganesan, B.; S. Buddhan; R. Anandan; R. Sivakumar and R. AnbinEzhilan (2010). Antioxidant defense of betaine against isoprenaline - induced myocardial infarction in rats. Mol. Biol. Rep., 37(3):131927.

Hassan, R.A.; Y.A. Attia and E.H. El-Ganzory (2005). Growth, carcass quality and serum constituents of slow growing chicks as affected by betaine addition to diets containing 1-Different levels choline. Int. J. Poult. Sci., 4:840-850.

Hassan, R.A.; E.H. El-Ganzoury; F.A. Abd El-Ghany and M.A. Shata (2003). Influence of dietary zinc supplementation with methionine or phytase enzyme on productive and reproductive performance for Mandarahstrain. Egypt. Poult. Sci., 23:761-785.

Holsheimer, J.P. and W.M.M.A. Janssen (1992). Limiting amino acids in low protein maize - soybean meal diets fed to broiler chicks from 3 to 7 weeks of age. Br. Poult. Sci., 32:141-158.

Junqueira, O.M.; A.C. de. Lauentiz; R.da. Silva Filardi; E.A. Rodrigues and E.M. Casartelli (2006). Effects of energy and protein levels on egg quality and performance of laying hens at early second production cycle. J. Appl. Poult. Res., 15:110-115.

Keshavaraz, K. and R.E. Austic (2004). The use of low-protein, low-phosphorus, amino acid and phytase - supplemented diets on laying hens performance and nitrogen and phosphorus excretion. Poult. Sci., 83:75-83.

Kettunen, H.; K. Tiihonen; S. Peuranen; M.T. Saarinen and J.C. Remus (2001). Dietary betaine accumulates in the liver and intestinal tissue and stabilizers the intestinal epithelial structure in healthy and coccidia - infected broiler chicks. Comp. Bioch. Physiol. Part A., 130:759-769.

Kidd, M.T.; B.J. Kerr; J.D. Firman and S.D. Boling (1996). Growth and carcass characteristics of broilers fed low-prtoein, threonine - supplemented diets. J. Appl. Poult. Res., 5:180-190.

Konca, Y.; F. Kirkpinar; S. Mert and E. Yaylak (2008). Effects of betaine on performance, carcass, bone and blood characteristics of broilers during natural summer temperatures. J. of Anim. and Vet. Adv., 7(8):930-937.

Koreleski, J. and S. Swiatkiewicz (2009). Laying performance and nitrogen balance in hens fed semiorganic diets with different energy and methionine level. J. Anim. Feed Sci., 18: 305-312.

Leeson, S.; J.D. Summers and L.J. Caston (2001). Response of layers to low nutrient density diets. J. Appl. Poult. Res., 10: 46-52.

Lesson, S. and J.D. Summers (1991). Commercial poultry Nutrition Published by Uni. Books P.O.Box 1326. Guelph and Ontario, Canada pp: 20-21.

McDevitt, R.M.; S.Mack and I.R. Wallis (2000). Can betaine partially replace or enhance the effect of methionine by improving broiler growth and carcass characteristics? Br. Poult. Sci., 41:463-480.

Molitoris, B.A. and D.H. Baker (1976). The choline requirement of broiler chicks during the seventh weeks of life. Poult. Sci., 55:220-224.

Nahashon, S.N.; N.A. Adefope; A. Amenyenu and D. Wright (2007). Effect of varying concentrations of dietary crude protein and metabolizable energy on laying performance of pearl Grey Guinea fowl hens. Poult. Sci., 86:1793-1799.

Nahm, K.H (2002). Efficient feed nutrient utilization to reduce pollutants in poultry and swine manure. Crit. Rev. Environ. Sci. Technol., 32:1-16.

Namroud, N.F.; M. Shivazad and M. Zaghari (2008). Effects of fortifying low crude protein diet with crystalline amino acids on performance, blood ammonia level and excreta characteristics of broiler chicks. Poult. Sci., 87:2250-2258.

NRC (1994). National Research Council. Nutrient Requirements of poultry $9^{\text {th }}$ rev. ed. Nat. Acad. Press, Washington, DC.

Naulia, A.H.; and M.A. Singh (2002). Effect of dietary protein and supplemental fat on performance of laying hens. Int. J. Poult. Sci., 4(12):1986-1989.

Park, J.H.; C.W. Kang and K.S. Ryu (2006). Effects of feeding betaine on performance and blood hormone in laying hens. Kor. J. Poult. Sci., 33: 323-328.

Petronine, P.G.; E.M. Deangelis; A.F. Broghetti and K.P. Wheeler (1992). Modulation by betaine of cellular responses to osmotic stress. J. Biochem., 282:69-73.

Ratriyanto, A.; R. Mosenthin;E. Bauer and M. Eklund (2009). Metabolic osmoregulatory and nutritional functions of betaine in monogastric animals. Asian-Aust. J. Anim. Sci., 22(10):1461-1476.

Remus, J.C.; E.E.M. Pierson and M. Hruby (2004). The evaluation of betaine and enzymes in coccidian challenged broilers. XXII Poultry Congress, Istanbul, Turkey, 6: 8-13. 
Rima, O. (2013). The metabolic burden of methyl donor deficiency with focus on the betainehomocysteinemethyltransferase pathway. Nutrients 5, 3481-3495.

Rostangose, H.C. and Pack (1996). Can betaine replace supplemental Dl-methionine in broiler diet? J. Appl. Poult. Res., 5:150-154.

SAS (1994). SAS/STAT® User's Guide: Statistics ver. 6.04, Fourth Edition SAS Institute Inc., Cary, NC.

Saunderson, C.L. and J. Mackinaly (1990). Changes in body weight, composition and hepatic enzyme activities in response to dietary methionine, betaine and choline levels in growing chicks. Br. J. Nutr., 63: 339-349.

Sayed, M.A.M. and J. Downing (2011). The effects of water replacement by oral rehydration fluids with or without betaine supplementation on performance, acid-base balance, and water retention of heatstressed broiler chickens. Poult. Sci., 90:157-167.

Schutte J.B.; J. Jong; W. Smink and M. Pack (1997). Replacement value of betaine for DL-methionine male broiler chicks. Poult. Sci., 76:321-325.

Seedor, J.G.; H.A. Quarruccio and D.D. Thompson (1991). The biophosphonate alendronate (MK-217) inhibits bone less due to ovariectomy in rats. J. of bone and Mineral Res., 6:339-346.

Sinova, C.A.; E.J. Moreno; J.M.G. Abvarado; M. Frikha; R. Lázaro and G.G. Mateos (2010). Influence of source of soybean meal and lysine content of the diet on performance and total tract apparent retention of nutrition in broilers from 1 to 36 days of age. Poult. Sci., 89(7):1440-1450.

Tollba, A.A.H. and A.H.I. El-Nagar (2008). Increasing stocking density of Egyptian laying hens by using: 3-Increasing protein level and Betaine supplementation. Egypt. Poult. Sci., 28:745-766.

Virtanen, P.W. and L.Rossi (1995). Effects of betaine on methionine requirement of broiler under various envirsity of sydne (Abst.)

Wang, Y.; Z.Xu and J. Feng (2004). The effect of betaine and methionine on growth performance and carcass characterstics in meat duck. Anim. F. Sci., Tech., 116:151-159.

Zayed, S.M.A. (2012). Physiological studies on turkeys. M.Sc. Thesis, Fac. Agric., Mansoura Univ. Mansoura. Egypt. 
Table (1). Composition and calculated chemical analysis of the starter and grower experimental basal diets.

\begin{tabular}{|c|c|c|c|c|}
\hline \multirow{2}{*}{ Ingredients $\%$} & \multicolumn{2}{|c|}{ Starter (0-3 weeks) } & \multicolumn{2}{|c|}{ Grower (4-5 weeks) } \\
\hline & Control & $\mathrm{T}_{1}-\mathrm{T}_{5}$ diets* & Control & $\mathrm{T}_{1}-\mathrm{T}_{5}$ diets $*$ \\
\hline Yellow corn & 46.45 & 54.44 & 54.44 & 60.0 \\
\hline Soybean meal (44\%) & 36.20 & 30.15 & 30.15 & 25.29 \\
\hline Full fat soya & 9.00 & 9.00 & 9.00 & 9.00 \\
\hline Soya + Sunflower oil & 3.65 & 2.00 & 2.00 & 1.5 \\
\hline Mono calcium phosphate & 1.85 & 1.68 & 1.68 & 1.68 \\
\hline Limestone & 1.60 & 1.48 & 1.48 & 1.48 \\
\hline Salt (Nacl) & 0.40 & 0.40 & 0.40 & 0.40 \\
\hline DL-Methionine & 0.34 & 0.20 & 0.20 & 0.12 \\
\hline L-Lysine HCL & 0.08 & 0.22 & 0.22 & 0.10 \\
\hline Vitamin \& Min. Mix $* *$ & 0.30 & 0.30 & 0.30 & 0.30 \\
\hline Choline chloride $50 \%$ & 0.13 & 0.13 & 0.13 & 0.13 \\
\hline Total & 100.00 & 100.00 & 100.00 & 100.00 \\
\hline \multicolumn{5}{|c|}{ Calculated chemical analysis $* * *$} \\
\hline Crude protein $\%$ & 22.93 & 20.93 & 20.93 & 19.06 \\
\hline $\mathrm{ME}(\mathrm{Kcal} / \mathrm{kg})$ & 3030 & 3029 & 3029 & 3055 \\
\hline Calcium $\%$ & 1.04 & 0.95 & 0.95 & 0.95 \\
\hline Available phosphorus $\%$ & 0.56 & 0.56 & 0.56 & 0.51 \\
\hline Lysine \% & 1.48 & 1.40 & 1.40 & 1.21 \\
\hline Methionine \% & 0.72 & 0.55 & 0.55 & 0.45 \\
\hline Methionine + cysteine $\%$ & 1.09 & 0.87 & 0.87 & 0.77 \\
\hline \multicolumn{5}{|c|}{ 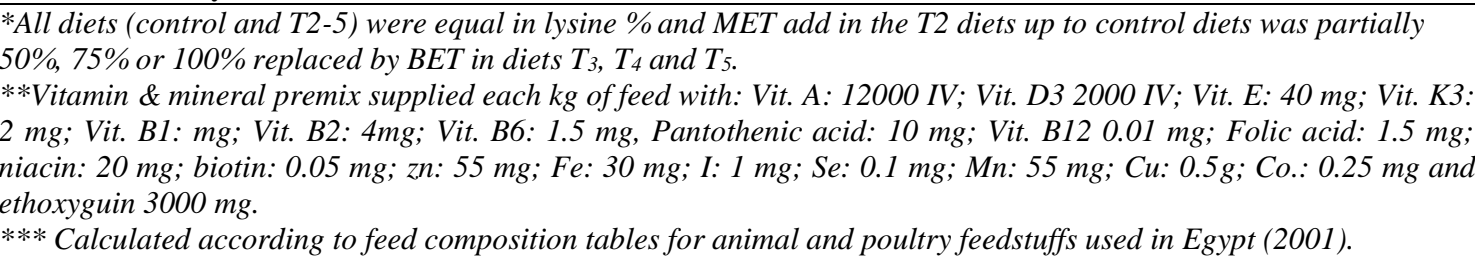 } \\
\hline
\end{tabular}

Table (2).Effect of dietary treatments on growth performance of broiler chicks.

\begin{tabular}{|c|c|c|c|c|c|c|c|c|}
\hline \multirow{2}{*}{ Items } & \multicolumn{6}{|c|}{ Dietary treatments } & \multirow{2}{*}{ SE } & \multirow{2}{*}{ Sig. } \\
\hline & control & $\mathrm{T} 1$ & $\mathrm{~T} 2$ & T3 & $\mathrm{T} 4$ & T5 & & \\
\hline Initial bodyweight $(\mathrm{g})$ & 47.83 & 46.83 & 46.67 & 47.33 & 47.00 & 46.83 & 1.43 & N.S. \\
\hline \multicolumn{9}{|c|}{$0-3$ weeks of age } \\
\hline Body weight gain (g) & $837.50^{\mathrm{a}}$ & $761.38^{\mathrm{b}}$ & $769.33^{\mathrm{b}}$ & $814.33^{\mathrm{ab}}$ & $809.00^{\mathrm{ab}}$ & $783.83^{\mathrm{ab}}$ & 12.89 & $*$ \\
\hline Feed intake $(\mathrm{g})$ & 1100.00 & 1184.00 & 1104.00 & 1188.00 & 1152.00 & 1149.00 & 26.55 & NS \\
\hline $\begin{array}{l}\text { Feed conversion ( } \mathrm{g} \\
\text { feed/g gain) }\end{array}$ & $1.31^{\mathrm{c}}$ & $1.55^{\mathrm{a}}$ & $1.43^{\mathrm{b}}$ & $1.46^{\mathrm{b}}$ & $1.42 \mathrm{~b}$ & $1.46^{\mathrm{b}}$ & 0.019 & $*$ \\
\hline \multicolumn{9}{|c|}{$4-5$ weeks of age } \\
\hline Body weight gain (g) & 1151.97 & 1152.43 & 1125.67 & 1091.03 & 1084.27 & 1128.33 & 42.35 & NS \\
\hline Feed intake $(\mathrm{g})$ & $2265.00^{\mathrm{b}}$ & $2427.00^{\mathrm{a}}$ & $2224.00^{\mathrm{b}}$ & $2292.00^{\mathrm{b}}$ & $2278.00 \mathrm{~b}$ & $2283.00^{\mathrm{b}}$ & 42.00 & $*$ \\
\hline $\begin{array}{l}\text { Feed conversion ( } \mathrm{g} \\
\text { feed/g gain) }\end{array}$ & 1.96 & 2.12 & 1.98 & 2.10 & 2.10 & 2.04 & 0.098 & NS \\
\hline \multicolumn{9}{|c|}{$0-5$ weeks of age } \\
\hline Body weight gain (g) & 1989.74 & 1914.27 & 1895.00 & 1905.37 & 1893.27 & 1912.17 & 39.44 & NS \\
\hline Feed intake $(\mathrm{g})$ & $3355.00^{\mathrm{b}}$ & $3611.00^{\mathrm{a}}$ & $3328.00^{\mathrm{b}}$ & $3480.00^{\mathrm{ab}}$ & $3430.00^{\mathrm{ab}}$ & $3432.00^{\mathrm{ab}}$ & 66.85 & $*$ \\
\hline $\begin{array}{l}\text { Feed conversion (g } \\
\text { feed/g gain) }\end{array}$ & $1.68^{\mathrm{b}}$ & $1.89^{\mathrm{a}}$ & $1.76^{\mathrm{ab}}$ & $1.83^{\mathrm{ab}}$ & $1.81^{\mathrm{ab}}$ & $1.80^{\mathrm{ab}}$ & 0.055 & $*$ \\
\hline
\end{tabular}


Table (3). Effect of dietary treatments on PI and PEF of broiler chicks

\begin{tabular}{lcccccccc}
\hline \multirow{2}{*}{ Items } & \multicolumn{9}{c}{ Dietary treatments } & \multirow{2}{*}{ SE } & \multirow{2}{*}{ Sig. } \\
\cline { 2 - 7 } & Control & T1 & T2 & T3 & T4 & T5 & & $*$ \\
PI $^{1}$ & $121^{\mathrm{a}}$ & $104^{\mathrm{b}}$ & $110^{\mathrm{ab}}$ & $107^{\mathrm{ab}}$ & $107^{\mathrm{ab}}$ & $109^{\mathrm{ab}}$ & 2.42 & $*$ \\
$\mathrm{PEF}^{2}$ & $347^{\mathrm{a}}$ & $297^{\mathrm{b}}$ & $315^{\mathrm{ab}}$ & $305^{\mathrm{ab}}$ & $305^{\mathrm{ab}}$ & $311^{\mathrm{ab}}$ & 7.18 & $*$ \\
\hline
\end{tabular}

Means within the same row or column with superscripts are significantly different. $N S=$ Non significant Sig. = Significance, $*(P \geq 0.05), N S=$ Non-significant. I: North (1981), 2: Emmert (2000).

Table (4). Effect of feeding different experimental diets on carcass characteristics of broiler chicks slaughtered at 5 weeks of age.

\begin{tabular}{|c|c|c|c|c|c|c|c|c|}
\hline \multirow{2}{*}{ Items } & \multicolumn{6}{|c|}{ Dietary treatments } & \multirow{2}{*}{ SE } & \multirow{2}{*}{ Sig. } \\
\hline & Control & $\mathrm{T} 1$ & $\mathrm{~T} 2$ & $\mathrm{~T} 3$ & $\mathrm{~T} 4$ & T5 & & \\
\hline $\begin{array}{l}\text { Live body weight } \\
\text { (g) }\end{array}$ & 1996.6 & 1755.00 & 1711.67 & 1711.67 & 1818.33 & 1860.00 & 69.86 & NS \\
\hline $\begin{array}{l}\text { Carcass weight } \\
\text { (g) }\end{array}$ & 1460.00 & 1260.00 & 1201.67 & 1288.33 & 1368.33 & 1253.33 & 50.08 & N.S \\
\hline Carcass $\%$ & 73.1 & 71.8 & 70.2 & 75.3 & 75.3 & 73.2 & 49.10 & NS \\
\hline Liver & $1.44^{\mathrm{b}}$ & $2.57^{\mathrm{a}}$ & $2.24^{\mathrm{ab}}$ & $2.38^{\mathrm{ab}}$ & $2.06^{\mathrm{ab}}$ & $2.33^{\mathrm{ab}}$ & 0.22 & $*$ \\
\hline Gizzard & 1.18 & 1.24 & 1.27 & 1.38 & 1.16 & 0.97 & 0.11 & NS \\
\hline Heart & 0.33 & 0.49 & 0.48 & 0.46 & 0.54 & 0.39 & 0.09 & NS \\
\hline Giblets & $2.94^{\mathrm{b}}$ & $4.29^{\mathrm{a}}$ & $3.99^{\mathrm{a}}$ & $4.21^{\mathrm{a}}$ & $3.76^{\mathrm{a}}$ & $3.70^{\mathrm{ab}}$ & 0.25 & $*$ \\
\hline Total edible parts & $76.09^{\mathrm{ab}}$ & $76.08^{\mathrm{ab}}$ & $74.15^{b}$ & $75.07^{\mathrm{ab}}$ & $77.33^{\mathrm{a}}$ & $76.90^{\mathrm{a}}$ & 0.76 & $*$ \\
\hline Abdominal fat & 1.69 & 1.68 & 1.77 & 2.01 & 1.61 & 2.41 & 0.33 & NS \\
\hline
\end{tabular}

$a, b$ Means in the same raw with different superscripts in the same raw are significantly $(P \leq 0.05)$ different. N.S.: non-significant.

Table (5). Effect of dietary treatments on the economical efficiency (EE) of broiler chicks.

\begin{tabular}{lcccccc}
\hline \multirow{2}{*}{ Items } & \multicolumn{5}{c}{ Dietary treatments } \\
\cline { 2 - 6 } & Control & $\mathrm{T}_{1}$ & $\mathrm{~T}_{2}$ & $\mathrm{~T}_{3}$ & $\mathrm{~T}_{4}$ & $\mathrm{~T}_{5}$ \\
\hline Fixed price/chick (L.E.) & 8.00 & 8.00 & 8.00 & 8.00 & 8.00 & 8.00 \\
Price /1 kg feed (L.E.) starter & 3.708 & 3.517 & 3.590 & 3.583 & 3.579 & 3.575 \\
grower & 3.517 & 3.329 & 3.362 & 3.359 & 3.358 & 3.356 \\
Total feed cost/chick (L.E.) & 12.01 & 12.24 & 11.44 & 11.96 & 11.77 & 11.77 \\
Total cost (L.E.)/chick & 20.01 & 20.24 & 19.44 & 19.96 & 19.77 & 19.77 \\
Average live body weight kg & 2.037 & 1.961 & 1.942 & 1.953 & 1.940 & 1.959 \\
Total revenue LE/chick & 24.44 & 23.53 & 23.30 & 23.44 & 23.28 & 23.51 \\
Net revenue LE/ckick & 4.43 & 3.29 & 3.86 & 3.48 & 3.51 & 3.74 \\
Economical Efficiency (EE) & 22.14 & 16.26 & 19.86 & 17.44 & 17.75 & 18.92 \\
Relative EE. & 100 & 73 & 90 & 79 & 80 & 86 \\
\hline
\end{tabular}


Ali et al.

Table (7). Effect of different treatments on the fatty acids differentiation.

\begin{tabular}{lllllll}
\hline \multirow{2}{*}{ Fatty acids } & \multicolumn{5}{c}{ Different } & treatments \\
\cline { 2 - 7 } & Control & T1 & T2 & T3 & T4 & T5 \\
\hline Caprlyic acid C8 & 1.099 & 0.726 & 2.549 & 2.071 & 1.160 & 1.536 \\
Myristic acid C14 & 0.478 & 0.517 & 0.495 & 0.533 & 0.548 & 0.491 \\
Palmitic acid C16 & 25.919 & 25.423 & 25.952 & 26.424 & 25.004 & 25.168 \\
Palmitioleic acid C16:1 & 3.571 & 4.183 & 3.589 & 3.225 & 3.752 & 3.899 \\
Heptadecanoic acid C17 & 0.142 & 0.128 & 0.183 & 0.124 & 0.156 & 0.147 \\
Strearic acid C18 & 6.557 & 6.407 & 6.789 & 7.703 & 6.679 & 6.261 \\
Oleic acid C18.1 & 2.338 & 39.167 & 36.224 & 35.302 & 35.719 & 32.114 \\
Linoleic acid C18.2 & 16.631 & 19.119 & 16.303 & 17.044 & 19.312 & 18.581 \\
Linolenic acid C 18.3 & 0.674 & 0.775 & 0.691 & 0.711 & 0.813 & 0.841 \\
Behenic C22 & 0.151 & 0.108 & 0.164 & 0.176 & 0.181 & 0.244 \\
Ermcic C22:1 & 0.183 & - & 0.197 & 0.199 & 0.215 & 0.233 \\
Sat/unsat ratio\% & 1.47 & 0.53 & 0.63 & 0.66 & 0.56 & 0.61 \\
\hline
\end{tabular}

\section{تأثير إضافة الميثايونين و/أو البيتايين إلى علاثق منذفضة البروتين على: 1-الأداء الإنتاجى - صفات الذبيحة ـ الاراسة الاقتصادية لبدارى التسمين.}

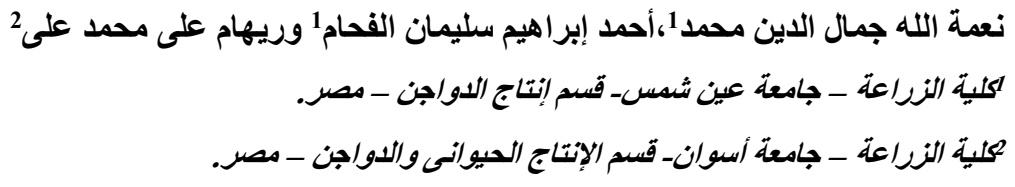

تهدف الدراسة إلى تقييم تأثثر استخدام كلاً من الميثايونين و/أوالبيتايين على الأداء الإنتاجى وصفات الذبيحة والعائد الاقتصادى

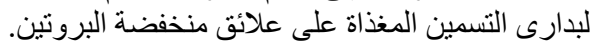

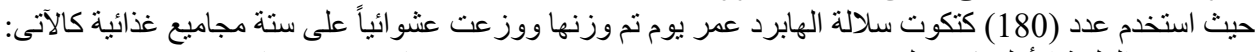

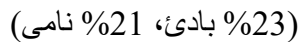

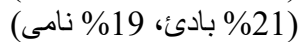

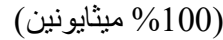

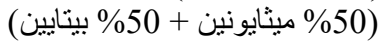

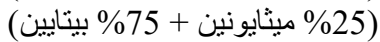
(100) بيتايين)

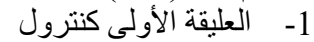

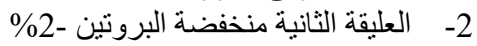
3- العليقة الثالثة مثل العليقة الثانية مع البنة 4- العليقة الر ابعة مثل العليقة الثانية مع العية

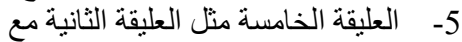

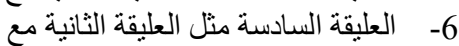

جميع العلائق متساوية المحتوى في الليسين وإضافة المئية الميثايونين فى العليقة الثانية حتى مستوى الكنترول (العليقة الأولى).

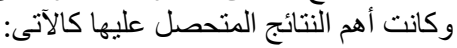

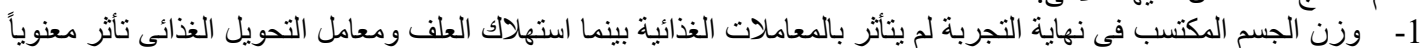

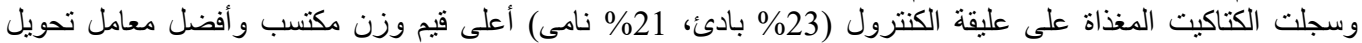

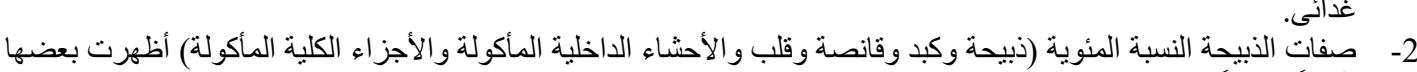

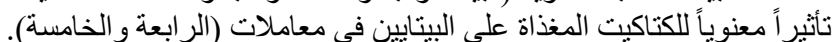

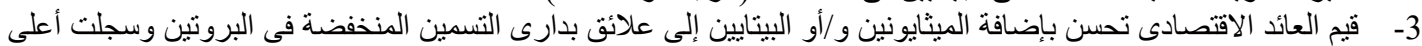

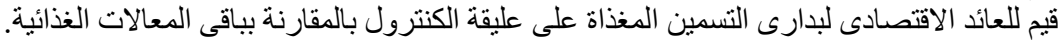

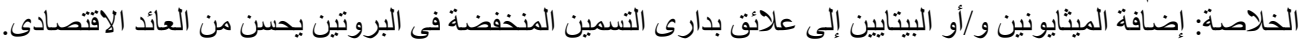

